APPLICATION OF THE TECHNIQUE OF ISOELECTRIC FOCUSING

TO THE STUDY OF HUMAN SERUM LIPOPROTEINS

\title{
AND THEIR APOPROTEINS
}

Angelo M. Scanu, M. D. , Celina Edelstein and Lawrence Aggerbeck

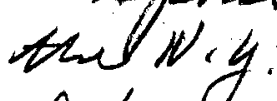

Departments of Medicine and Biochemistry, The University of Chicago

Pritzker School of Medicine, and Argonne Cancer Research Hospital,* Chicago, Illinois 60637
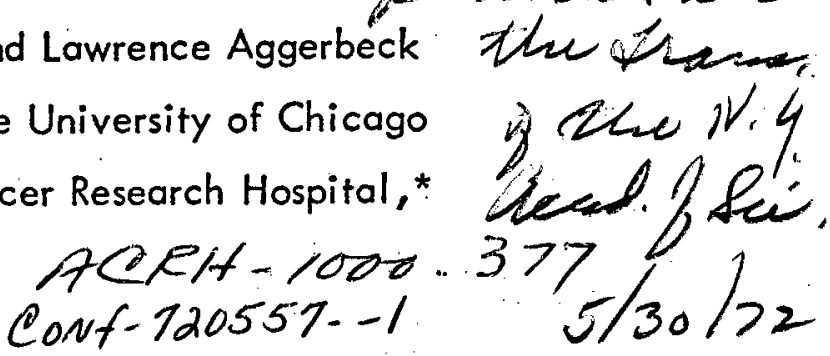

The technique of isoelectric focusing (IEF) has seen rather limited

application to the study of serum lipoproteins both from the preparative and analytical standpoints. Serum lipoproteins, which have lipids as their ligand, are commonly separated in the ultracentrifuge into classes differing in lipidprotein ratios, hydrated density, size and molecular weight. Serum lipoproteins have also been shown to differ in terms of charge and this has permitted their fractionation by electrophoretic techniques. ${ }^{1}$ Thus, in principle at least, IEF should prove valuable in the analysis of the various lipoprotein classes and, owing to the high analytical resolution of the technique, allow for their potential sub-fractionation. Moreover, IEF could also be extended to the analysis of the various lipoprotein polypeptides which can now be prepared in water-soluble essentially lipid-free form. ${ }^{2}$ In this report we will summarize our experience gained with the technique of IEF in the study of the major classes of human serum lipoproteins and of their corresponding protein moieties.

Materials and Methods

The lipoproteins employed in this study were isolated by ultra- 


\section{DISCLAIMER}

This report was prepared as an account of work sponsored by an agency of the United States Government. Neither the United States Government nor any agency Thereof, nor any of their employees, makes any warranty, express or implied, or assumes any legal liability or responsibility for the accuracy, completeness, or usefulness of any information, apparatus, product, or process disclosed, or represents that its use would not infringe privately owned rights. Reference herein to any specific commercial product, process, or service by trade name, trademark, manufacturer, or otherwise does not necessarily constitute or imply its endorsement, recommendation, or favoring by the United States Government or any agency thereof. The views and opinions of authors expressed herein do not necessarily state or reflect those of the United States Government or any agency thereof. 


\section{DISCLAIMER}

Portions of this document may be illegible in electronic image products. Images are produced from the best available original document. 
centrifugal flotation from sera of healthy male Caucasian donors after an overnight fasting. ${ }^{3} \mathrm{HDL}_{2}, \mathrm{HDL}_{3}$ and $\mathrm{LDL}$ were dialyzed extensively against $0.15 \mathrm{M}$ $\mathrm{NaCl}, \mathrm{pH} 7.0,10^{-3} \mathrm{M}$ EDTA and then against $0.001 \mathrm{M}$ phosphate buffer $\mathrm{pH} 7.0,10^{-3}$ M EDTA before electrofocusing. Preparations of apo $\mathrm{HDL}_{2}$ or apo $\mathrm{HDL}_{3}$, obtained by delipidation ${ }^{3,4}$ of either $\mathrm{HDL}_{2}$ or $\mathrm{HDL}_{3}$ were dissolved in $6 \mathrm{M}$ urea solutions immediately before analysis. Fractions III and IV were prepared by Sephadex G-200 chromatography as described previously. ${ }^{5}$ LDL was studied intact, after partial delipidation with ether, and after more complete extraction with 3:1 ethanol-ether. ${ }^{6}$ The ether-treated LDL was impoverished of neutral lipids, whereas ethanol-ether treatment produced a protein containing less than $1 \%$ phospholipids by weight.

$\therefore$ Apo LDL was studied in $8 \mathrm{M}$ urea. In the case of VLDL, only preparations delipidated by ethanol-ether were studied and in particular the portion of the apoprotein soluble in $0.1 \mathrm{M} \mathrm{Tris-} \mathrm{HCl} \mathrm{pH} \mathrm{8.2.7}$ The insoluble residue was removed by centrifugation, whereas the Tris-soluble peptides were dialyzed against $6 \mathrm{M}$ urea solutions. For electrofocusing, from 3 to $10 \mathrm{mg}$ of the above materials were used.

Preparative isoelectric focusing

All experiments were conducted at either $5^{\circ}$ or $15^{\circ}$ in a $110-\mathrm{ml}$ capacity electrofocusing column (No. 8101; LKB-Produkter AB, Stockholm), using LKB carrier ampholytes and an LKB (No. 8121) gradient mixer. The column was coated with silicon before use. The method employed was essentially that of "Vesterberg and Svensson. ${ }^{8}$ In the case of $\mathrm{HDL}_{3}$ or $\mathrm{HDL}_{3}$ a $1 \% \mathrm{FH} 4-6$ ampho- 
line solution was employed. The bottom of the column was first filled with the anode lock which contained $0.8 \%$ phosphoric acid and $48 \%$ sucrose. By employing an LKB gradient mixer, a sucrose gradient was prepared by placing the dense solution containing $48 \%$ sucrose and $3 / 4$ of the total amount of carrier ampholytes in chamber one. An equal volume of light solution containing $1-2 \mathrm{ml}$ of sample and $1 / 4$ of the total amount of carrier ampholytes was placed in chamber 2. After filling with this gradient, the column was cooled with running tap water at a temperature of $5^{\circ} \mathrm{C}$. A potentia! of 500 volts was applied and kept constant while the current decreased to a minimum usually within 48-72 hours from the start of the run. After isofocusing was established, fractions $1.5-2 \mathrm{ml}$ in volume were collected and $\mathrm{pH}$ measurements performed in a pH Meter PM 26 (Radiometer, Copenhagen, Denmark) using a Radiometer electrode (GK 2322C). Absorption readings at $280 \mathrm{~nm}$ were carried out in a Beckman-Gilford Spectrophotometer. The appropriate fractions were pooled and the ampholytes removed by dialysis.

IEF of apo $\mathrm{HDL}_{2}$ or apo $\mathrm{HDL}_{3}$ or their Sephadex fractions III and IV was conducted as for their parent lipoproteins with the exception that $6 \mathrm{M}$ urea solutions replaced $\mathrm{H}_{3} \mathrm{O}$. The reason for using the dissociating agent derives from the fact that apo HDL or sub-fractions tend to aggregate in aqueous solutions. 1,2

The conditions for analysis of infact LDL were the same as described - 1 for $\mathrm{HDL}_{2}$ or $\mathrm{HDL}_{3}$ with the exception that $2 \%$ ampholine solutions were used. In the case of ether-treated preparations (LDL-E) and apo LDL(etnanol-ether 
extraction), the fractionation was carried out in the presence of $8 \mathrm{M}$ urea. Before isoelectric focusing LDL-E was dialyzed extensively against $1 \%$ glycine buffer, $\mathrm{pH} 8.0,0.025 \%$ EDTA in the presence or absence of $8 \mathrm{M}$ urea. Apo LDL was added to $8 \mathrm{M}$ urea solutions and solubility in such medium was facilitated, al though not complete, by light sonication (Branson sonifier, $4^{\circ} \mathrm{C}, 50$ Watts, $10-15$ seconds). The clear solutions were dialyzed against $8 \mathrm{M}$ urea before analysis.

The method for separating the Tris-soluble peptides from apo VLDL was described previously. ${ }^{7}$ In such a case, prefocusing of a $6 \%$ solution of ampholytes $(\mathrm{pH} 4-6)$ was carried out in the presence of $6 \mathrm{M}$ urea for 60 hours. After this run, only the gradient comprised in the $\mathrm{pH}$ range 4.35-4.85 was utilized since it was established that about $90 \%$ of the protein was within this $\mathrm{pH}$ range. After completion of the run, the appropriate pooled fractions were freed of the amptiolytes by either dialysis against $2 \mathrm{M} \mathrm{NaCl}$ or passage through Sephadex G-50 columns $(30 \times 1.5 \mathrm{~cm})$ equilibrated and eluted with $0.1 \mathrm{M}$ Tris buffer, $\mathrm{pH} 8.0,0.5 \mathrm{M} \mathrm{NaCl}, 4 \mathrm{M}$ urea. Methods of analysis of lipoprotein fractions after electrofocusing

From the analytical standpoint, the techniques of polyacrylamide gel electrophoresis (PAGE) in either $8 \mathrm{M}$ urea or $0.1 \%$ SDS were used. ${ }^{5}$ The reactivity of each fraction was tested against specific antibodies prepared in the rabbit against LDL, HDL, apo HDL and sub-fractions III, IV and $V$. In some of the specimens, amino acid analysis was conducted after acid hydrolysis $(6 \mathrm{~N} \mathrm{HCI})$ under conditions described before. ${ }^{3}$ When lipo- 
proteins were studied, lipid analysis in pooled samples were conducted

according to previously described techniques. ${ }^{3}$ Protein determinations were carried out by the Lowry method. 9

Analytical isoelectric focusing on PAGE

The method followed was essentially that by Wrigley ${ }^{10}$ using Coomassie blue dye in a methanol-acetic acid solution.

\section{Results}

Studies on $\mathrm{HDL}_{2}$ and $\mathrm{HDL}_{3}$ (Fig. $\mathrm{TA}$ and $\mathrm{B}$ )

The two lipoprofeins were isofocused in the $\mathrm{pH}$ gradient of 4-6, suggested by preliminary experiments in the $\mathrm{pH} 3-10$ range. After 24 hours, there was a major fraction, which focused at $\mathrm{pH} 5.3$ and comprised about $80 \%$ of the total protein applied. Two additional minor fractions were focused at $\mathrm{pH} 4.75$ and 4. 34, respectively. The same electrofocusing profile was observed after 48 hours and 72 hours runs. Refocusing of the major fraction (apparent $p l \approx 5.31$ ) in the same $\mathrm{pH}$ 4-6 gradient produced a single component with no change in pI values. The results with $H D L_{3}$ were essentially similar to $\mathrm{HDL}_{3}$ although major and minor fractions indicated some splitting into sub-components. The apparent pl values of the observed components are listed in Table 1. A problem encountered in these studies was that a total protein load of above $3 \mathrm{mg}$ there was an isoelectric precipitation which occurred within the first 24 hours of the runs. This poblem was prevented by conducting the experiments in the presence of $6 \mathrm{M}$ urea. However, under these conditions some modification of HDL apparently 11 occurred. For instance, $\mathrm{HDL}_{3}$, after a 46 hour run, exhibited a major peak 
with an apparent $\mathrm{pl}$ of 5.85 and minor peaks with $\mathrm{pl}$ of 5.60,5.29 and 4.63. It is known that urea can facilitate delipidation of lipoproteins ${ }^{2}$ and this would be expected to be associated with changes in surface charge.

An analysis of the major fraction obtained from either $\mathrm{HDL}_{2}$ and $\mathrm{HDL}_{3}$ revealed that it consisted of the intact lipoprotein containing the major polypeptides, III and IV, or apo HDL, in about the same ratio (3:1) as occurring in the original products (Fig. 2). On the other hand, the two minor fractions isolated at $\mathrm{pH} 4.75$ and 4.35 were found to contain less than $10 \%$ phospholipid and to be made essentially of fraction III. The findings were corroborated by immunological means.

Studies on apo $\mathrm{HDL}_{2}$, apo $\mathrm{HDL}_{3}$ and sub-fractions

An analysis of apo $\mathrm{HDL}_{2}$ gave an isoelectric focusing profile characterized by a major peak with an apparent pI of 5.58, a second major component with pl of 4.94 and three minor peaks with apparent $\mathrm{pl}$ of 4.8, 4.7 and 4.5, respectively (Fig. 3). By both $8 \mathrm{M}$ urea-PAGE or SDS-PAGE these peaks were found to contain the Sephadex III, IV and $V$ with the distribution indicated in Table 2. No re-run of these fractions was attempted. Apo $\mathrm{HDL}_{3}$ gave similar results; only there was less of fraction $V$.

Fractions III, IV and V, separated from apo $\mathrm{HDL}_{2}$ by. Sephadex $\mathrm{G}-200$ chromatography in $8 \mathrm{M}$ urea, were, each analyzed by isoelectric focusing in a $\mathrm{pH}$ 4-6 gradient. Fraction III exhibited two components with $\mathrm{pl}$ values of 5. 30 and 5.42 (Fig. 4). In turn, the two major fractions of III, $\mathrm{III}_{a}$ and $\mathrm{III}_{b}$, obtained by DEAE column chromatography ${ }^{\prime \prime}$ were found to give a single peak by IEF in the $\mathrm{pH} 4-6$ range. Each of these components gave also a single 
narrow band in $8 M$ urea-PAGE and SDS-PAGE.

Fraction IV has been shown in this laboratory to be made of two identical or nearly identical subunits, each having a molecular weight of about 8,500 daltons and linked together by a single disulfide bridge. ${ }^{12,13}$ The IV protomer in the reduced and carboxymetholated form was analyzed by isoelectric focusing in the $\mathrm{pH} 4-6$ range. A single component with an apparent $\mathrm{pl}$ of 4.98 was observed (Fig. 5), this in good agreement with the data on whole apo HDL.$A$ small shoulder was observed, but its significance not assessed.

Fraction $\vee$ gave a number of peaks, the major ones having apparent $\mathrm{pl}$ of $4.51,4.58,4.73$ and 4.97 . The results are in accord with the heterogeneity of this fraction shown by ion-exchange chromatography by 8 M urea-PAGE or SDS-PAGE. ${ }^{5}$ A comparison between DEAE and IEF fractions is in progress. Studies on LDL

Intact LDL (d 1.030-1.040). --The experiments were carried out in 1\% and $2 \%$ ampholine in the $\mathrm{pH} 4-6$ range. A constant complication in these studies was the early onset (within the first 12 hours) of a ring of precipitate, the intensity of which appeared roughly proportional to the amount of lipoprotein applied to the column ( 1 to $3 \mathrm{mg}$ lipoprotein protein). The final isoelectric focusing profile, presented in Fig. 6, gave a single major peak with an apparent pI of 4.46. This figure cannot be considered reliable since readings were taken either before current had reached stabilization or after current had stabilized, but diffusion of the precipitated material had occurred. No studies in the presence of urea were carried out. 
LDL-E. --The ether-extracted LDL proved more amenable for study, although the results were not unequivocal. When analyzed in the $\mathrm{pH} 3-10$ range in the absence of urea (Fig. 7) a major and a minor peak were observed with an apparent pl of 5.85 and 4.85 , respectively. When the fractions $23-42,45-53$ and 56-93 (see Fig. 8) were pooled and analyzed by $8 M$ urea-PAGE, the (23-42) fraction was characterized by fast-moving components, whereas the $(45-53)$ fraction was made of bands which migrated close to the origin (Fig. 8). The same conclusions were reached by SDS-PAGE in the presence of $8 \mathrm{M}$ urea. The (56-93) fraction produced no bands. The amino acid composition of the major (45-53) fraction proved very similar to that of whole apo LDL. $L D L-E$, analyzed by preparative isoelectric focusing in the presence of 8. $M$ urea, exhibited a major peak with $\mathrm{pl} \approx 5.62^{*}$ and minor ones with apparent pl of $6.40,6.23,4.98$ and 4.71 (Fig. 9). A re-run of the pooled fraction between tubes $36-62$ in $8 \mathrm{M}$ urea gave a major $(\mathrm{pl} \approx 5.64)$ and a minor peak $(\mathrm{pI} \approx 5.43)$, the latter probably representing a component produced during fractionation (Fig. 10). This was suggested by the fact that no significant differences were noted with the $8 \mathrm{M}$ urea-PAGE patterns of the pooled fractions all showing a slow-migrating component. On the other hand, significant differences were noted in the amino acid composition of fractions $36-47,48-61$ and $62-73$ of Fig. 10 as shown in Table 3. The actual significance of these data is not apparent and, only tentatively, they may be considered as supporting the chemical heterogeneity of LDL protein, suggested by other studies. ${ }^{2}$

*This result was not consistently obtained and $\mathrm{pI}$ values of 6.0 and 6.4 were recorded for this major fraction. 
LDL extracted with ethanol-ether, apo LDL. --All experiments were carried out in the presence of $8 \mathrm{M}$ urea. A typical isoelectric focusing profile by apo LDL in the $\mathrm{pH}$ 3-10 range is presented in Fig. 11. Two major peaks are seen with $\mathrm{pl} \approx 6.42$ and 4.88 respectively. By SDS-PAGE in $8 \mathrm{M}$ urea, the first fraction contained high molecular weight components $(50-70,000)$ contrary to the second fraction which was made of the fast-running low-molecular weight polypeptides $(10-20,000)$ almost exclusively. The 44-61 fraction gave no gel pattern probably because of the low protein concentration. All of the studied pooled fractions (21-27, 31-39 and 44-61 in Fig. 11) showed significant differences in amino acid composition suggesting that they may be composed of distinct chemical entities. Essentially similar results were obtained with apo LDL-8 $M$ urea in the $\mathrm{pH} 4-6$ gradient. Here again, a clear separation was obtained between components of high and low-molecular weight. A summary of the apparent pl values obtained with the LDL studies is given in Table 4. The variability in results among LDL preparations may be noted. However, it should be stressed that in each case the amount of lipid in each preparation, and in particular of phospholipids, may have contributed to the observed pI values.

Studies on apo VLDL

Since they have been reported previously ${ }^{7}$ only a summary of those results will be presented here. The experiments were carried out in $6 \mathrm{M}$ urea in the $\mathrm{pH}$ range of 4.35-4.85. A study of the Tris-soluble peptides permitted the , 1 separation of four components with the characteristics reported in Table 5. The results were in good agreement with those by Brown et al. 14 obtained by a com- 
bination of Sephadex and DEAE-cellulose chromatography with the added advantage that the IEF allowed for comparatively better recoveries and for identification of a peptide previously unrecognized. Analytical isoelectric focusing in polyacrylamide gel

This technique was particularly useful in the study of apo HDL and of the sub-fractions. The pattern of apo $\mathrm{HDL}_{2}$ (Fig. 12) indicates the same number and position of the bands isolated from this protein on a preparative scale. However, the most useful application of this technique was the checking of the purity of products separated and purified by gel filtration and DEAE cellulose chromatography. ${ }^{11,12}$ As a whole the results of this analytical technique compared favorably with those obtained with preparative isoelectric focusing.

\section{Discussion}

The results of our studies indicate that the technique of IEF, both analytical and preparative, may find a useful application to the study of serum lipoproteins and its derivatives. According to the experience gained in this laboratory with the three major serum lipoprotein classes: VLDL, LDL and HDL, the favorable aspects of IEF can be summarized as follows: (1) it was capable of separating in good yields some of the Tris-soluble from apo VLDL; (2) it served as a good check for purity of polypeptides previously isolated by other methodologies; (3) it was more valuable in the study of the polypeptides than of their parent lipoproteins. On the basis of the above, IEF has seen a continuing use in our laboratory and has taken a definite place among the techniques utilized in the study of the structure of serum lipoproteins. However, although appreciative 
of the real value of IEF, we have become aware of the many limitations of this technique, at least in terms of the methods followed in this laboratory and the type of materials employed. In our opinion, what IEF cannot do is: (1) be used on a real preparative scale because of the ready tendency of lipoproteins or derivatives to precipitate at their isoelectric point, a phenomenon which is proportional to protein concentration; (2) insure lipoprotein stability during either electrofocusing or the stage of removal of the ampholites, a step which is usually more effectively accomplished by gel filtration; (3) prevent, in the case where urea solutions are used, protein carbamylation since an ion-free system is needed for the study. Among the other drawbacks, although not insurmountable, were the difficulties in completely freeing the specimens of the ampholites, and the complete lack of knowledge of the chemical nature and possible variabilities in the composition of these carriers.

The useful knowledge gained in the current study was that in the case of the polypeptides analyzed, IEF did not resolve further the products obtained by the combined techniques of gel filtration and DEAE cellular chromatography. For these reasons and also on the basis of the limitations listed above, we have elected to essentially limit the use of IEF to the analysis of purified polypeptides from the various serum lipoproteins. However, we wish to point out that these limitations may not necessarily be valid for other lipoprotein systems and only direct experience may allow for definitive conclusions.

Finally, mention ought to be made of the work by Blaton and Peeters, 15 , whose results appear at variance with those obtained in our studies. However, 
the data are not strictly comparable since those authors carried out the fractionation of their lipid-free polypeptides in the absence of any dissociating agent, an omission known to promote aggregation of these materials. 1,2 Thus, the discrepancies in the observed $\mathrm{pl}$ values may be accounted for by the differences in the physical state of the materials analyzed. With reference to the report by Albers et al. ${ }^{16}$ on the "R-Threonine"*, one of the polypeptides of human serum apo HDL, the observed five components by IEF were, at least in part, artifactual probably owing to protein carbamylation during the step preceding either Sephadex G-200 chromatography in $8 \mathrm{M}$ urea or during IEF also carried out in $8 \mathrm{M}$ urea. The potential occurrence of this problem has been discussed recently. 11

* The authors named the polypeptide on the basis of the presumed "C-terminal" amino acid residue. It has now been established that the correct C-terminus is glutamine. 11,17 
Summary

The techniques of analytical and preparative isoelectric focusing (IEF) were applied to the study of human serum very low-density lipoproteins (VLDL), low-density lipoproteins (LDL) and high-density lipoproteins (HDL) and their polypeptides (apo VLDL, apo LDL and apo HDL) obtained by extraction with organic solvents. LDL was also analyzed after partial extraction with ethyl ether. As a whole, the technique proved of limited value on the preparative scale because of the ready tendency of the products analyzed to precipitate at their isoelectric point. IEF was found more valuable on the analytical scale in the characterization of products separated and purified by chromatographic procedures. 


\section{Acknowledgments}

This work was supported by grants from the United States Public

Health Service (HE-08727), the American Heart Association ("70-753)

and the Chicago and Illinois Heart Association (C71-6).

One of the authors (AMS) is the recipient of USPHS Research Career

Development Award (HE-24,867).

One of the authors (LA) is a USPHS pre-doctoral trainee on Grant HD-00001 from the National institute of Child Health and Human Development.

Footnote to Title Page

* Operated by the University of Chicago for the United States Atomic Energy Commission.

t Abbreviations:,$V L D L=$ very low-density lipoprotein of $d<1.006$;

$L D L=$ low-density lipoprotein of d 1.019-1.063; $\mathrm{HDL}_{2}=$ high density lipoprotein of d 1.063-1. 125; $\mathrm{HDL}_{3}=$ high density lipoproteins of $d 1.125-1.21 \mathrm{~g} / \mathrm{ml}$. Apo VLDL, apo LDL, apo $\mathrm{HDL}_{2}$ and apo $\mathrm{HDL}_{3}$ refer to the protein moiety of each of the lipoprotein classes after delipidation. LDL-E = LDL extracted with ethy! ether. III, IV and $V$ are the major polypeptides of apo HDL. SC-IV refer to the 1 reduced and carboxymethylated product. 


\section{References}

1. SCHUMAKER, V. N. \& G.H. ADAMS. 1969. Circulating lipoproteins. Annu. Rev. Biochem. 38: 113.

2. SCANU, A. M. \& C. WISDOM. 1972. Serum lipoproteins: Structure and function. Annu. Rev. Biochem. 42: in press.

3. SCANU, A. M. 1966. Forms of human serum high density lipoprotein.

J. Lipid Res. 7: 295.

4. SCANU, A. M. \& C. EDELSTEIN. 1971. Solubility in aqueous ethanol of the small molecular weight peptides of serum very, low-density and high-density lipoproteins. Relevance to the problem of delipidation of plasma lipoproteins. Anal. Biochem. 44: 576.

5. SCANU, A. M. , J. TOTH, C. EDELSTEIN, S. KOGA \& E. STILLER. 1969. Fractionation of human serum high density lipoproteins in urea solutions. Evidence for polypeptide heterogeneity. Biochemistry 8: 3309.

6. GRANDA, J. L. \& A. M. SCANU. 1966. Solubilization and properties of the apoproteins of the very low- and low-density lipoproteins of human serum. Biochemistry 5: 3301.

7. ALBERS, J. \& A. M. SCANU. 1971. Isoelectric fractionation and characterization of polypeptides from human serum low-density lipoproteins. Biochim. Biophys. Acta, 236: 29.

8. VESTERBERG, O. \& H. SVENSSON. 1966. Isoeléetric fractionation; analysis and characterization of ampholytes in natural pH gradients. IV. Further studies on the resolving power in connection with separation of myoglobins. Acta Chem. Scand. , 20: 820. 
9. LOWRY, O. H., N. J. ROSEBROUGH, A. L. FARR \& R. J. RANDALL.

1951. Protein measurement with the folin phenol reagent. J. Biol. Chem. 193: 265.

10. WRIGLEY, C. 1968. Gel electrofocusing: A technique for analyzing multiple protein samples by isoelectric focusing. Sci. Tools 15: 17.

11. EDELSTEIN, C. , C. T. LIM \& A. M. SCANU. 1972. On the subunit structure of the protein of human serum high density lipoprotein. I. A study of Sephadex fraction III. J. Biol. Chem. submitted.

12. SCANU, A. M. , C. EDELSTEIN \& C. T. LIM. 1971. Effect of disulfide cleavage on the molecular weight of one of the polypeptides of serum high density lipoprotein. Fed. Eur. Biochem. Soc. Lett. 18: 305.

13. SCANU, A. M. , C. T. LIM \& C. EDELSTEIN. 1972. On the subunit structure of the protein of human serum high density lipoprotein. II. A study of Sephadex fraction IV. J. Biol. Chem. submitted.

14. BROWN, W. V., R. 1. LEVY \& D. S. FREDRICKSON. 1969. Studies of the proteins in human plasma very low density lipoproteins. J.: Biol. Chem. 244: 5687.

15. PEETERS, H. \& V. BLATON. 1970. Study of the protein moiety of low- and highdensity lipoproteins. In Atherosclerosis. R. J. Jones, Ed.: 182. SpringerVerlog, New York.

16. ALBERS, J. J., L. V. ALBERS \& F. ALADJEM. 1971. Isoelectric heterogeneity of the major polypeptide of human serum high density lipoproteins. Biochem. Med. 5: 48. 
17. KOSTNER, G. \& P. ALAUPOVIC. 1971. Studies on the composition and structure of plasma lipoproteins. $\mathrm{C}$ - and $\mathrm{N}$-terminal amino acids of the two unidentical polypeptides of human plasma apolipoprotein A. Fed. Eur. Biochem. Soc. Lett. 15: 320. 
TABLE 1

APPARENT PI VALUES OF HDL $\mathrm{OR} \mathrm{HDL}_{3}$ AFTER ISOELECTRIC FOCUSING AT PH 4-6

\begin{tabular}{cccc}
\hline Lipoprotein & \multicolumn{3}{l}{ Apparent pl } \\
\hline HDLa $(24 \mathrm{hrs})$ & 5.04 & 4.73 & 4.35 \\
$\mathrm{HDL}_{2}(48 \mathrm{hrs})$ & 5.10 & 4.81 & 4.34 \\
$\mathrm{HDL}_{2}(72 \mathrm{hrs})$ & 5.08 & 4.84 & 4.32 \\
$\mathrm{HDL}$ & $(72 \mathrm{hrs})$ & $(5.06,5.09,5.10)(4.99,4.84)(4.65,4.56)$ \\
\hline
\end{tabular}




\section{TABLE 2}

ISOELECTRIC FOCUSING OF HUMAN SERUM apo HDLa

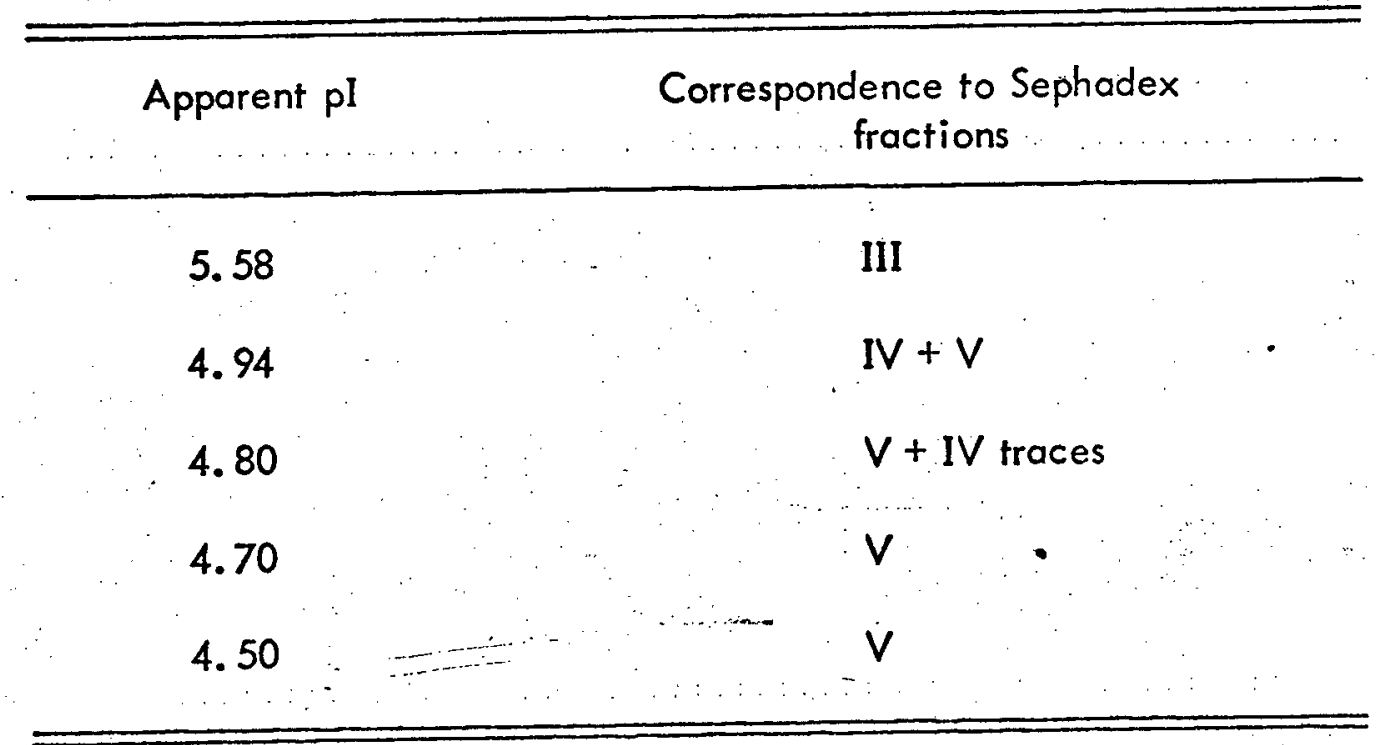




\section{TABLE 3}

AMINO ACID COMPOSITION OF THREE POOLED FRACTIONS

FROM ISOELECTRIC FOCUSING OF LDL-E IN FIGURE 10

(Aspartic acid $=100$ )

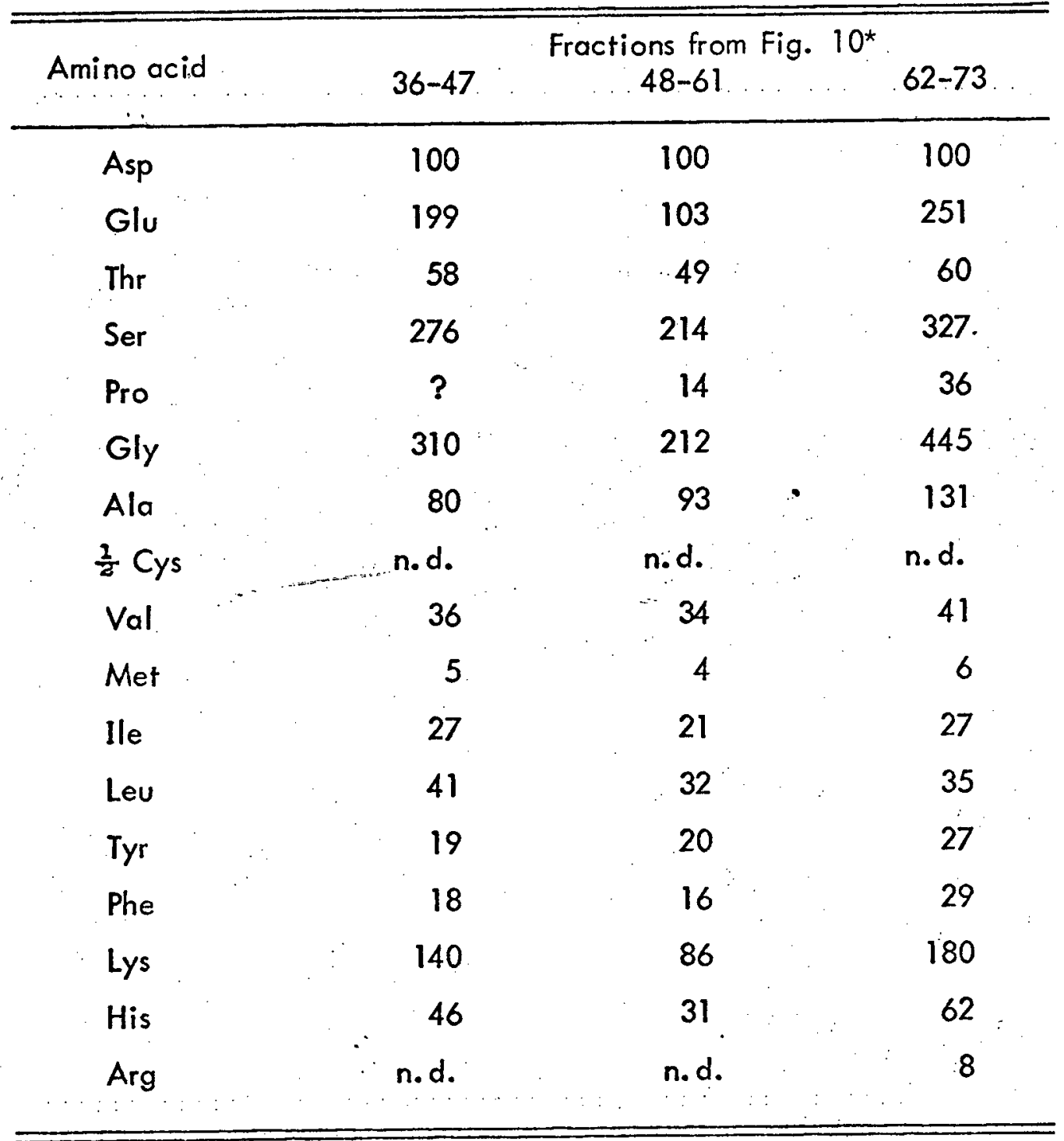

*Values adjusted to the nearest integer. 
TABLE 4

SUMMARY OF APPARENT PI VALUES OBTAINED BY ISOELECTRIC FOCUSING OF VARIOUS LDL PREPARATIONS

\begin{tabular}{|c|c|c|c|c|}
\hline LDL preparation & \multicolumn{4}{|c|}{ Peak position based on apparent pI } \\
\hline Intact LDL, no urea & 4.46 & & & \\
\hline LDL-E, no urea & 4.89 & 5.85 & & \\
\hline LDL-E in urea & $4.71 \quad 4.98$ & 5.62 & 6.23 & 6.40 \\
\hline Apo LDL in urea & 4.88 & & & 6.42 \\
\hline
\end{tabular}


SUMMARY OF RESULTS OBTAINED BY ELECTROFOCUSING

OF THE TRIS-SOLUBLE PEPTIDES OF SERUM apo VLDL*

\begin{tabular}{|c|c|c|c|c|c|c|c|}
\hline Fraction & $\begin{array}{l}\text { Apparent } \\
\text { pl }\end{array}$ & $\begin{array}{c}\% \\
\text { Distribution }\end{array}$ & $\begin{array}{l}\text { Characteristics of } \\
\text { amino acid composition }\end{array}$ & $\begin{array}{l}\mathrm{N}- \\
\text { Terminus }\end{array}$ & $\begin{array}{l}\mathrm{C}- \\
\text { Terminus }\end{array}$ & $\begin{array}{l}\text { Sialic acid } \\
\text { mole/mole } \\
\text { protein }\end{array}$ & $\begin{array}{c}\text { MW } \\
\text { apparent }\end{array}$ \\
\hline$A$ & 4.53 & 26 & $\begin{array}{l}\text { No cysteine or cystine } \\
\text { and isoleucine }\end{array}$ & Serine & Alanine & 2 & 10,000 \\
\hline B & 4.70 & 50 & same as Fraction A & Serine & Alanine & $\therefore$ & 10,000 \\
\hline C & 4.79 & 17 & $\begin{array}{l}\text { No cysteine or cystine } \\
\text { and histidine }\end{array}$ & Threonine & $\begin{array}{l}\text { Not } \\
\text { identified }\end{array}$ & 0 & 9,000 \\
\hline$D$ & 4.93 & 7 & $\begin{array}{l}\text { No cysteine or cystine } \\
\text { and isoleucine }\end{array}$ & $\begin{array}{l}\therefore \text { n.d. } \\
\therefore \quad \therefore\end{array}$ & Alanine & 0 & 10,000 \\
\hline
\end{tabular}

*Data from Albers and Scanu. 


\section{Figure Legends}

Fig. 1. Isoelectric focusing of human serum $\mathrm{HDL}_{3}$ (upper panel) and $\mathrm{HDL}_{3}$ (lower panel). Ampholine pH 4-6, concentration, 1\%, 48 hours, $5^{\circ} \mathrm{C}$.

Fig. 2. SDS-PAGE of major and minor components as in Fig. I carried out after delipidation. A. Whole apo $\mathrm{HDL}_{2}$ in $0.1 \% \beta$-mercaptoethanol; B. Unreduced apo $\mathrm{HDL}_{2}$; fraction III; fractions III + SC-IV; SC-IV.

Fig. 3. Isoelectric focusing of apo $\mathrm{HDL}_{3}$ in $6 \mathrm{M}$ urea. Ampholine $\mathrm{pH} 4-6$; $1 \%, 48 \mathrm{hrs}, 5^{\circ} \mathrm{C}$.

Fig. 4. Isoelectric focusing separation of apo HDLa fraction III (6 M urea), experimental conditions as in Fig. 3.

Fig. 5. Isoelectric focusing of apo $\mathrm{HDL}_{3}$ fraction IV (6 M urea). Experimental conditions as in Fig. 3.

Fig. 6. Isoelectric focusing of human serum LDL (d $1.030-1.040 \mathrm{~g} / \mathrm{ml})$. Ampholine $\mathrm{pH} \mathrm{4-6;2 \% ,12} \mathrm{hrs,} 15^{\circ} \mathrm{C}$.

Fig. 7. Isoelectric focusing of LDL-E (no urea). Experimental conditions : Ampholine $\mathrm{pH} 3-11,2 \%, 48 \mathrm{hrs}, 15^{\circ} \mathrm{C}$.

Fig. 8. $8 M$ urea-PAGE of IEF fractions from LDL E. A. Fractions (23-42);

B. Fractions (45-53) of Fig. 7.

Fig. 9. Isoelectric focusing of LDL-E in $8 \mathrm{M}$ urea. Experimental conditions: Ampholine $\mathrm{pH} 4-7,8 \%, 24 \mathrm{hrs}, 15^{\circ} \mathrm{C}$.

Fig. 10. Re-run of the major component from IEF run of LDL-E as in Fig. 9, but pH 5. 2-5.9, 2\%, $48 \mathrm{hrs}, 10^{\circ} \mathrm{C}$.

Fig. 11. Isoelectric focusing of apo LDL in $8 \mathrm{M}$ urea. Ampholine pH 3-10;

- $\quad 2 \%, 20 \mathrm{hrs}, 15^{\circ} \mathrm{C}$.

Fig. 12. Isogel of apo $\mathrm{HDL}_{3}$ in $6 \mathrm{M}$ urea. 

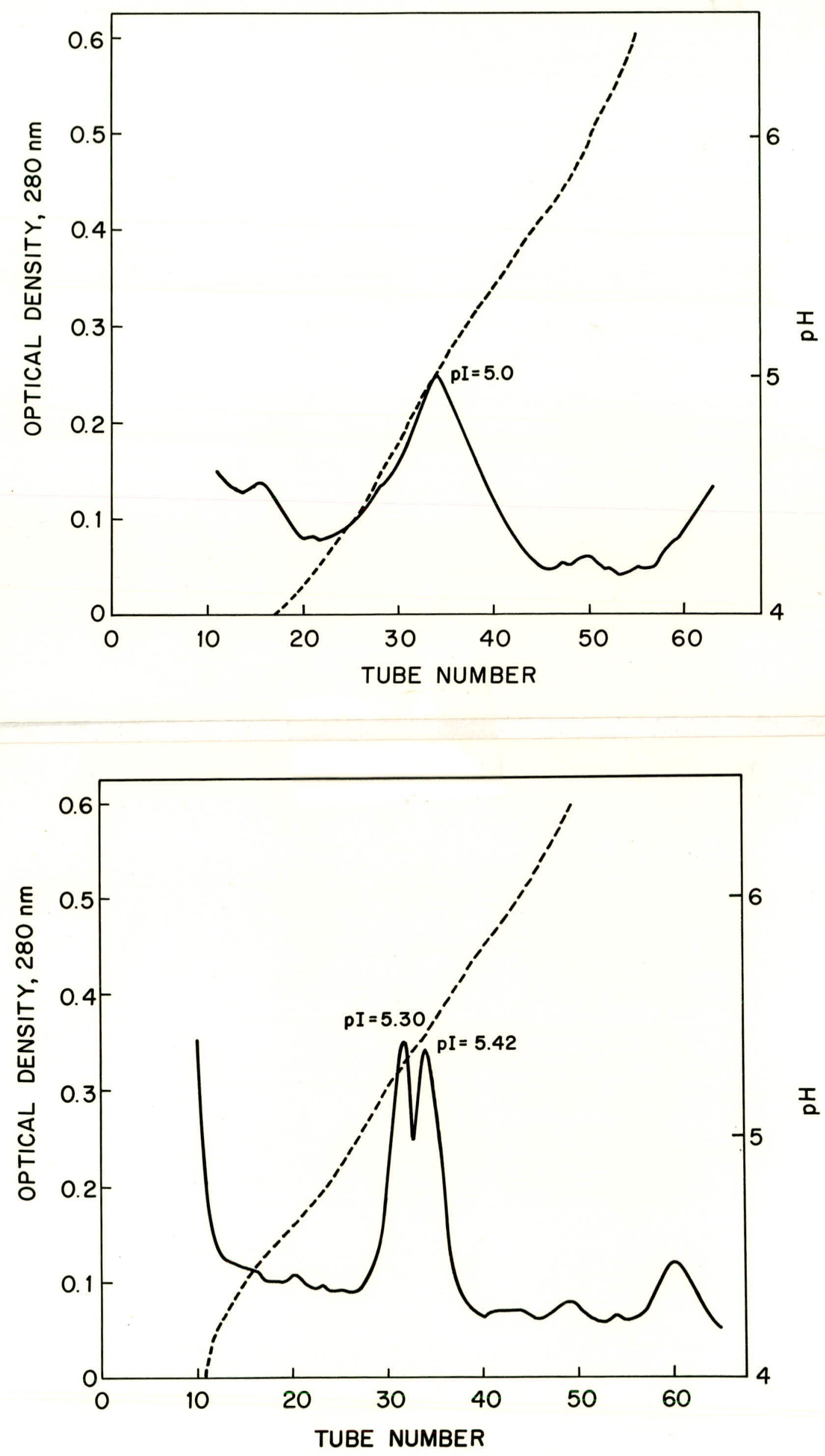

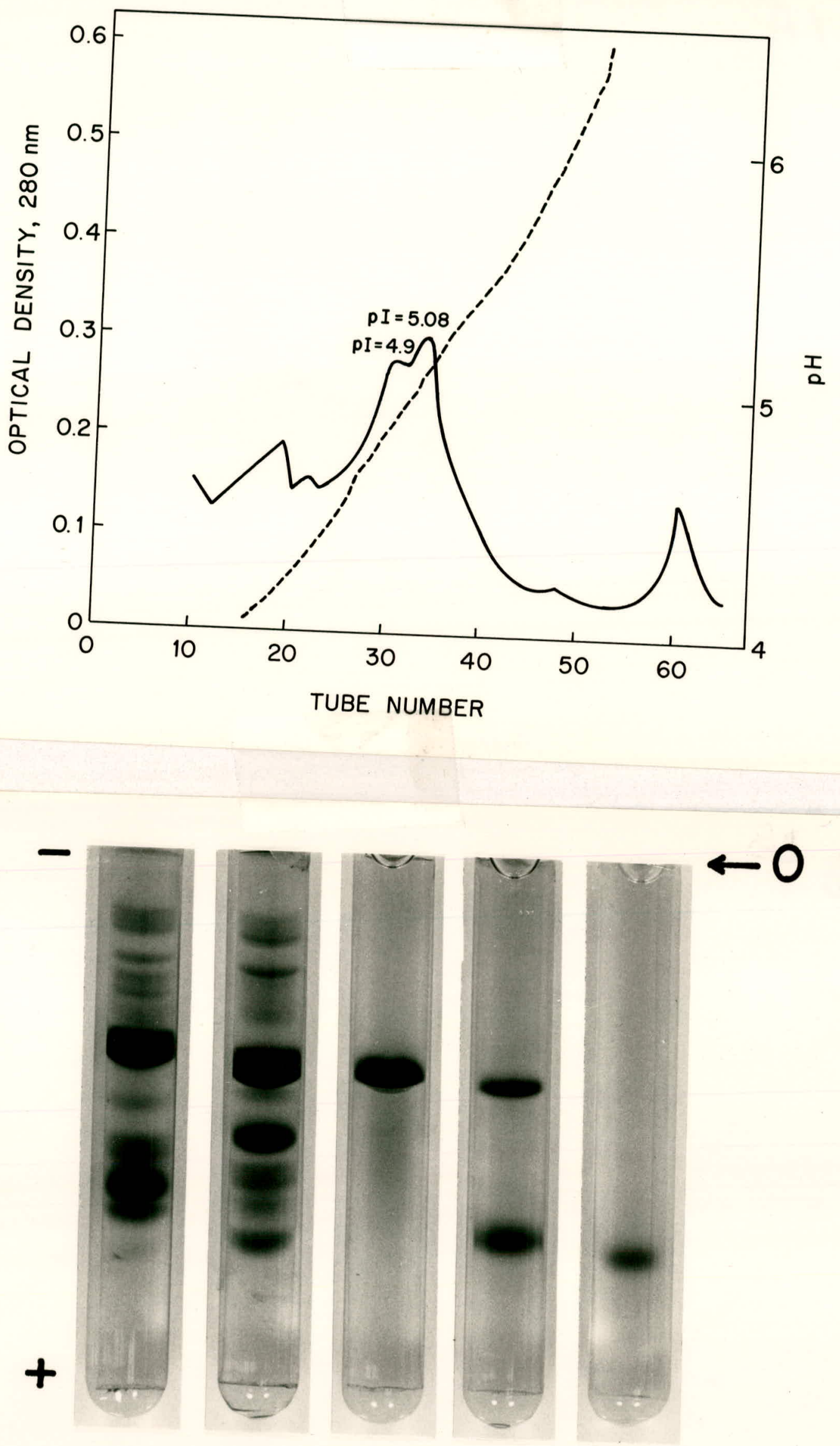

A B C D E 

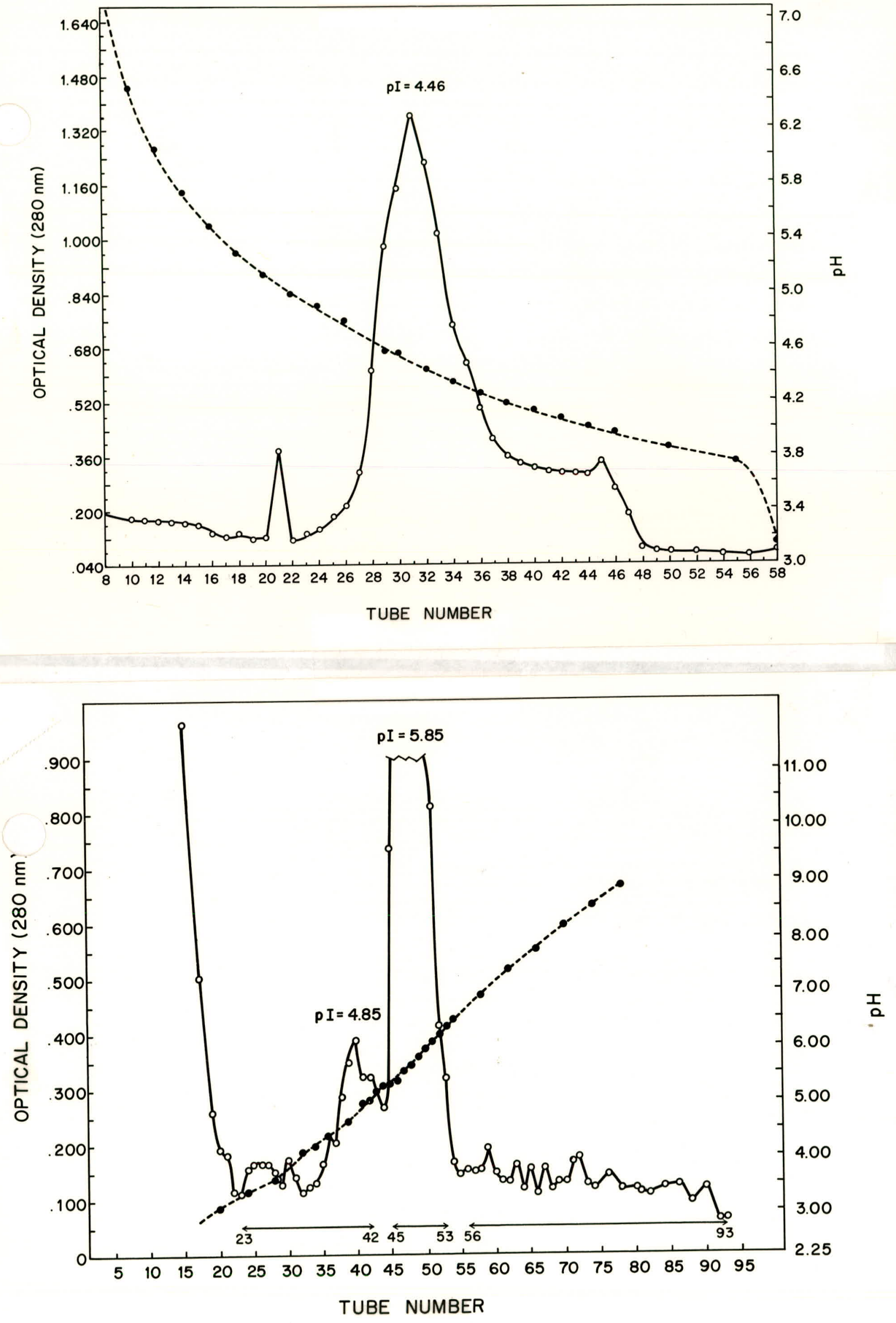

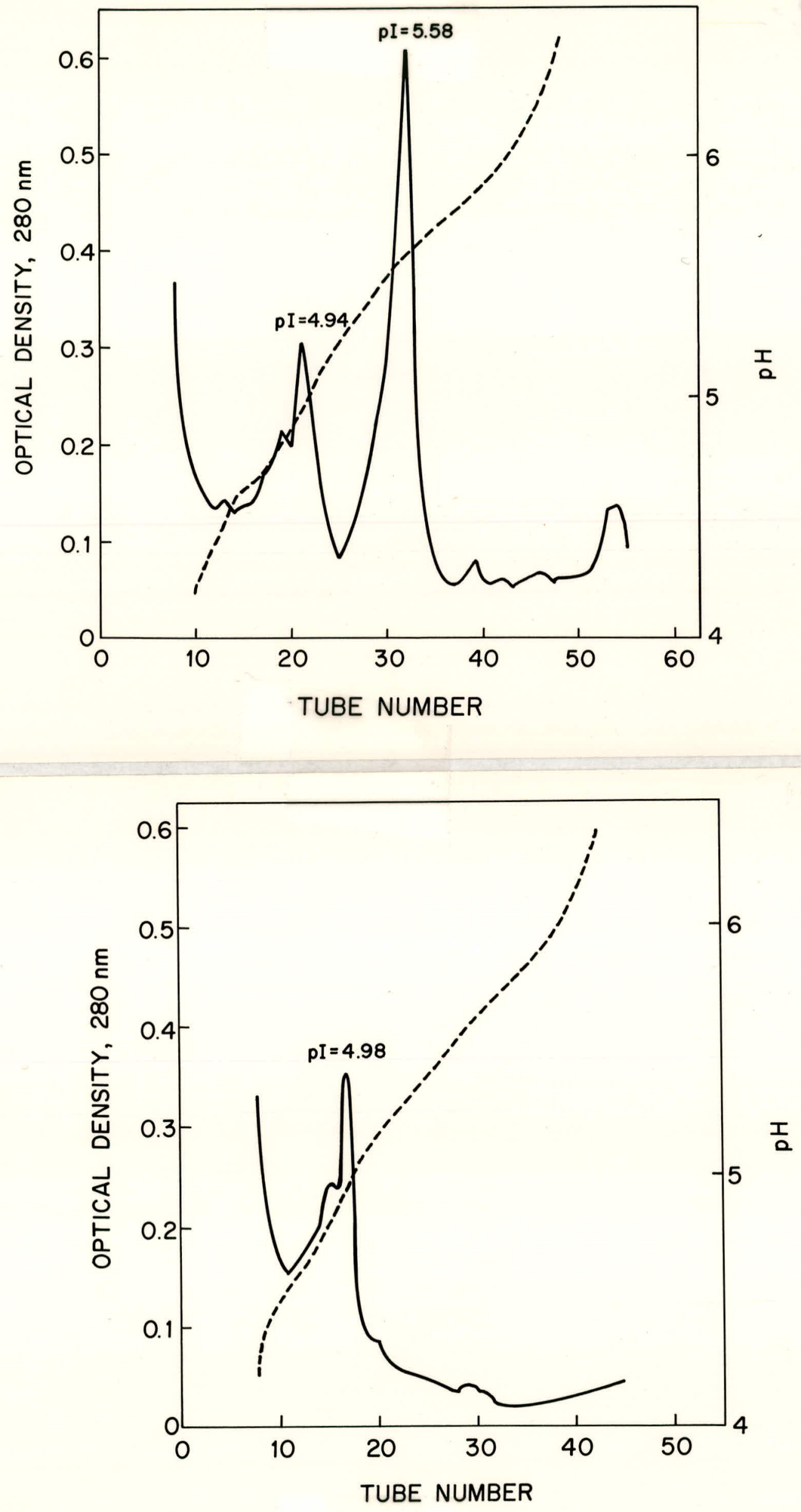

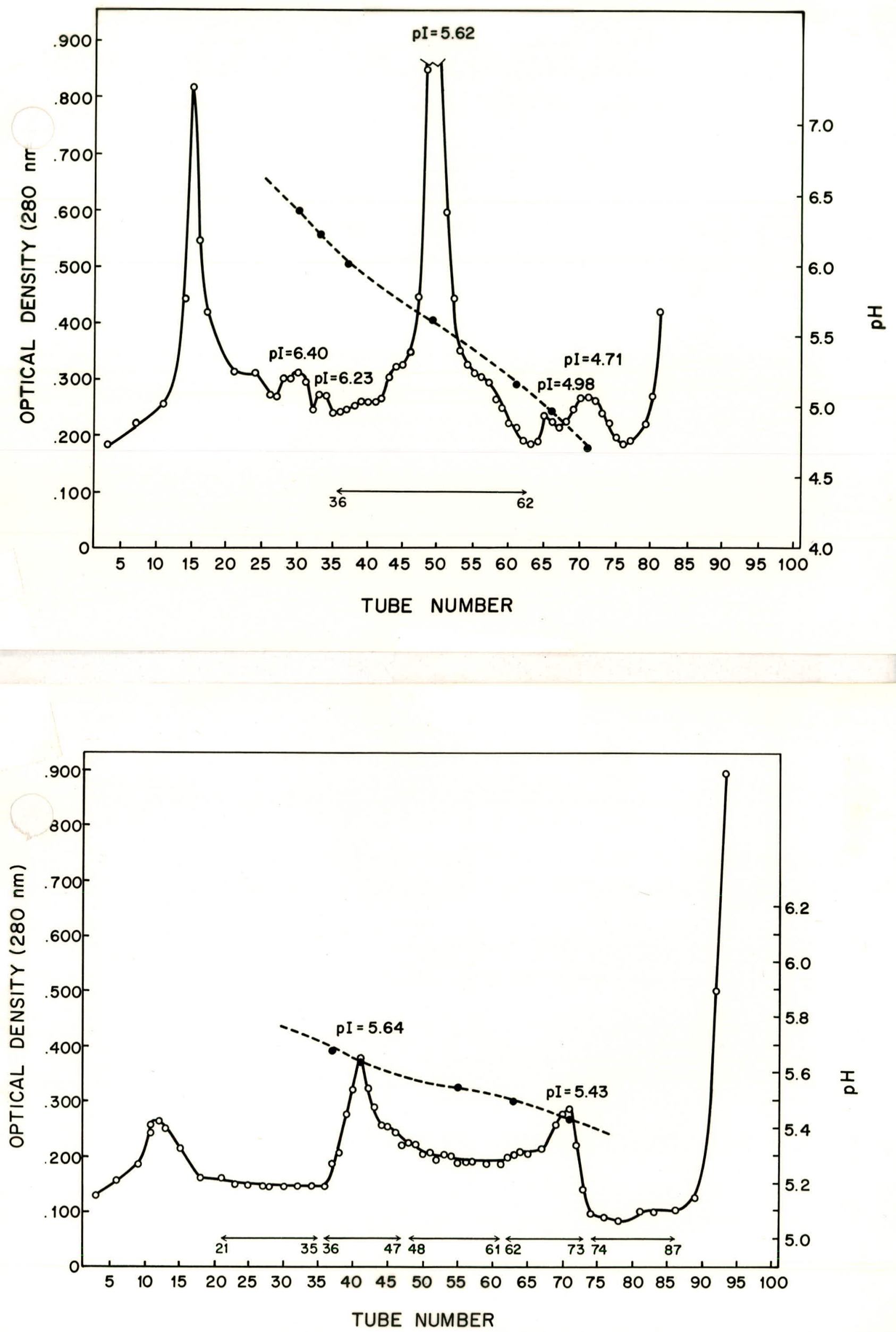

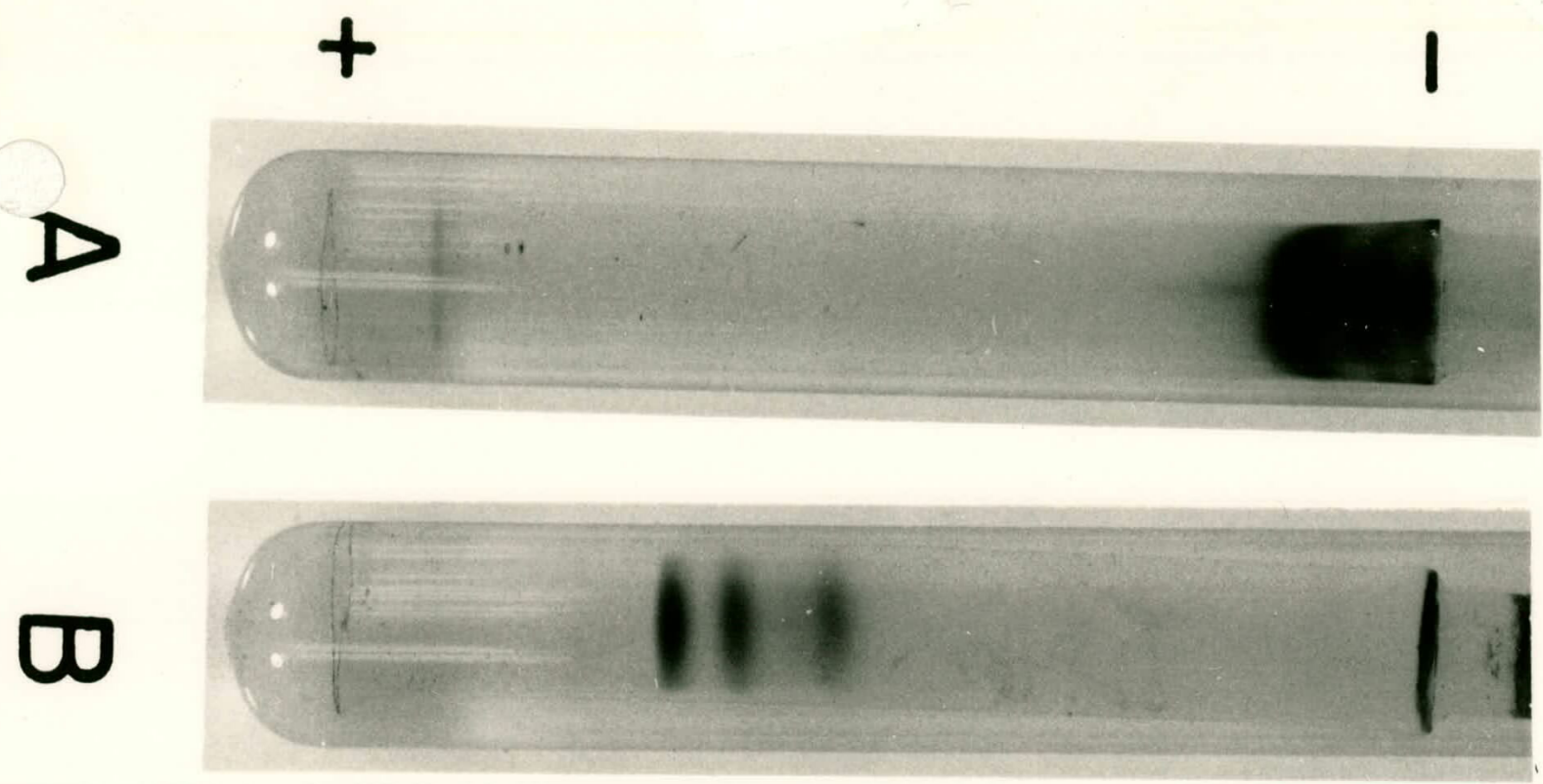

$\uparrow$

o

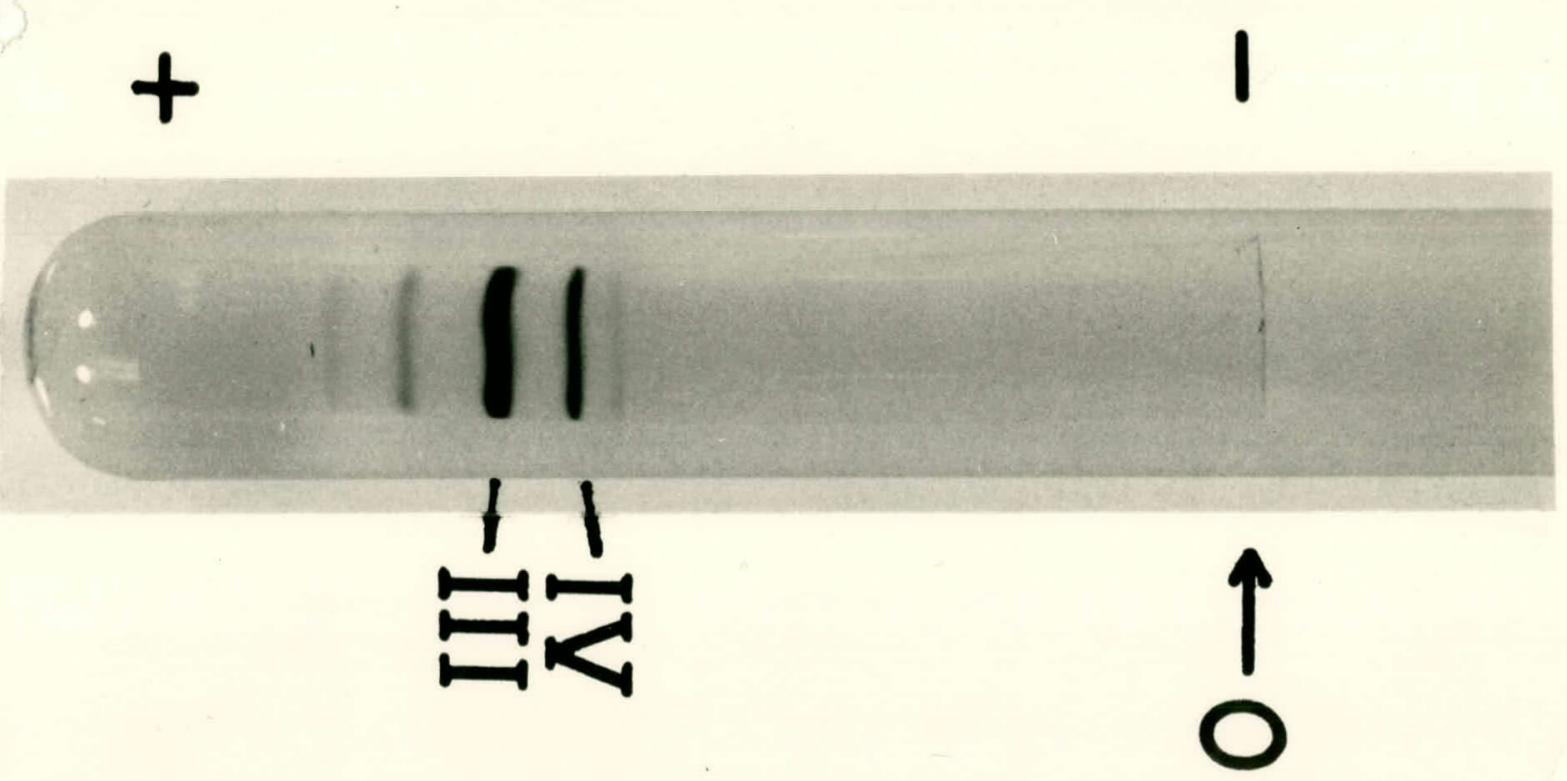



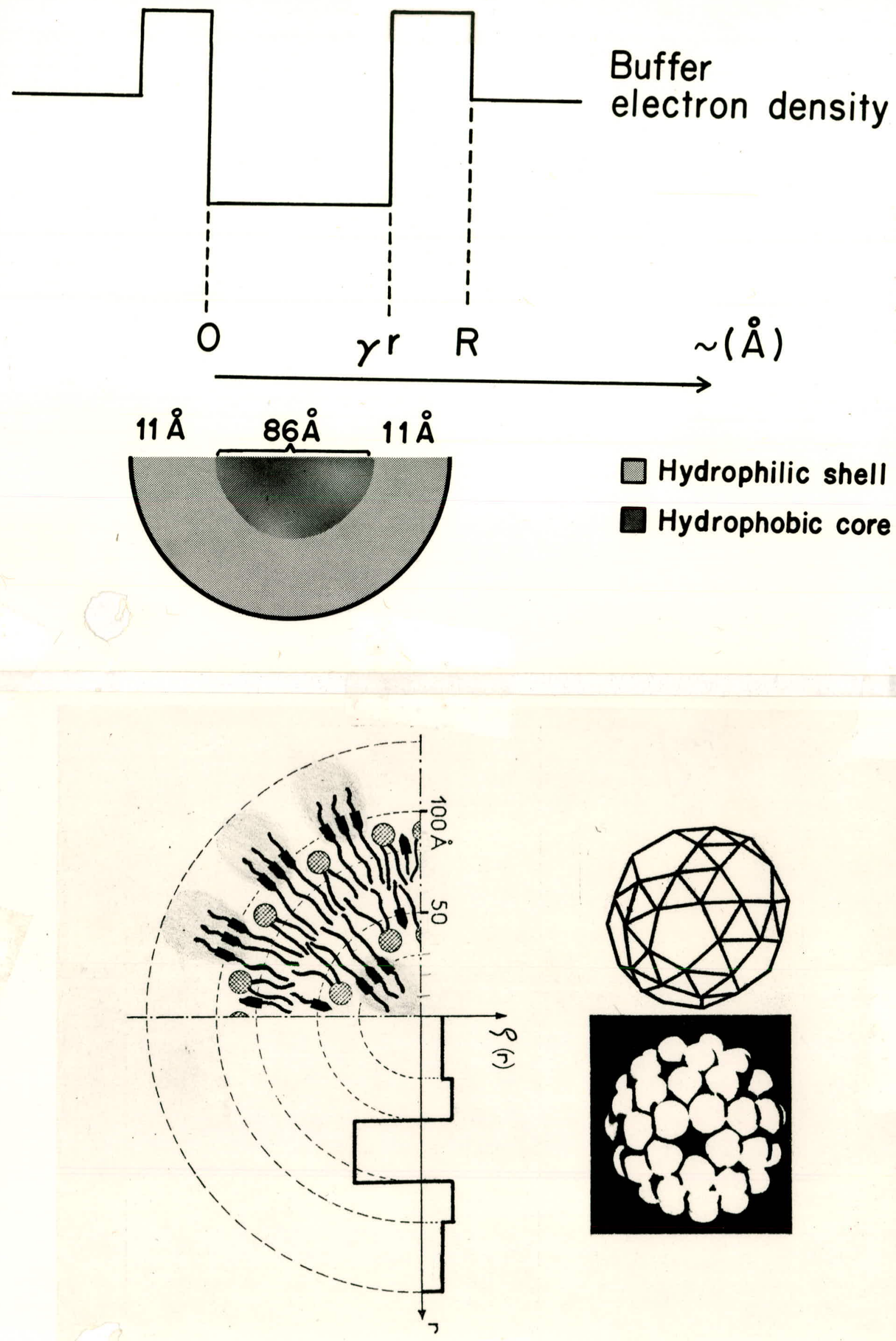


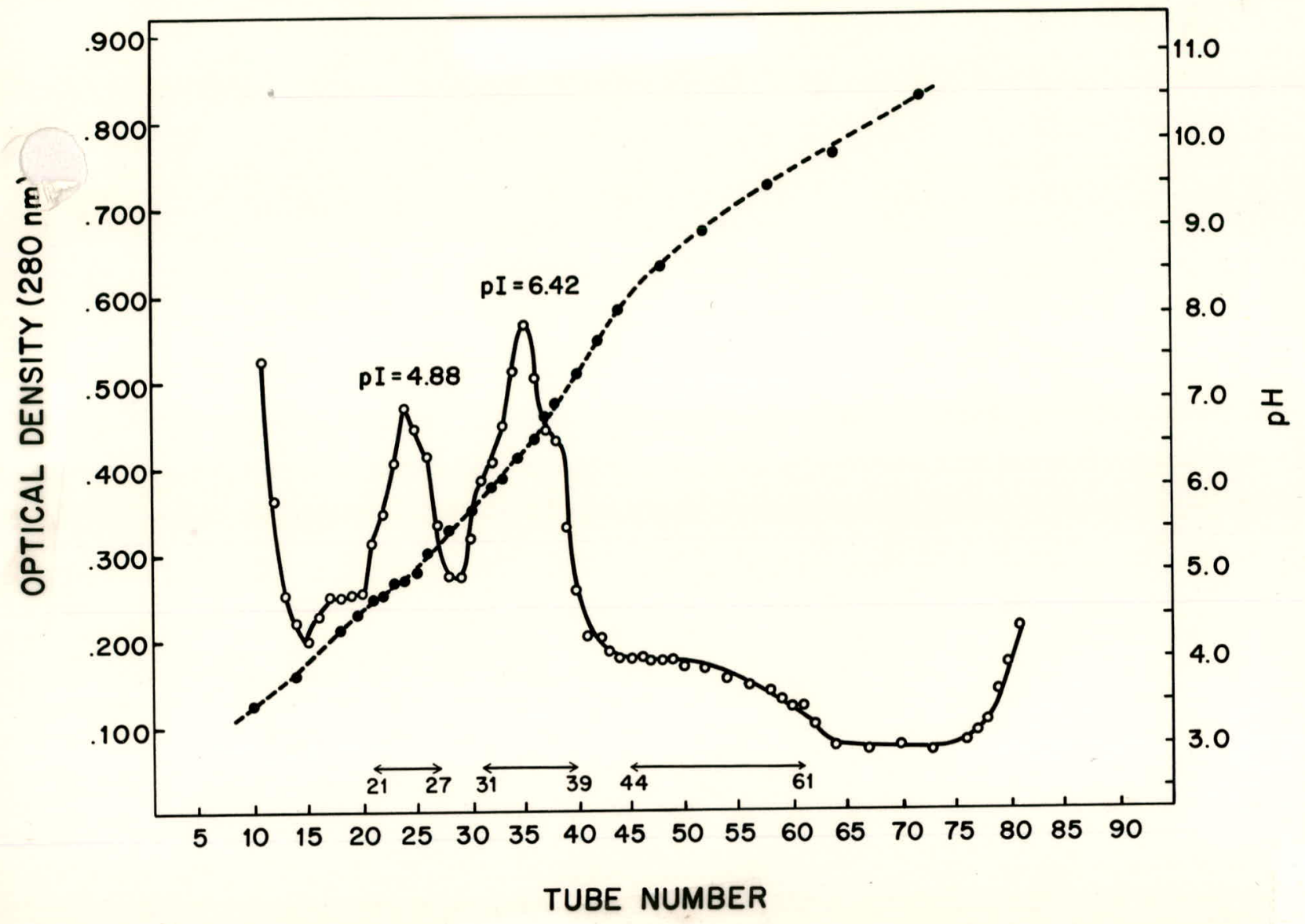

GEL FILTRATION

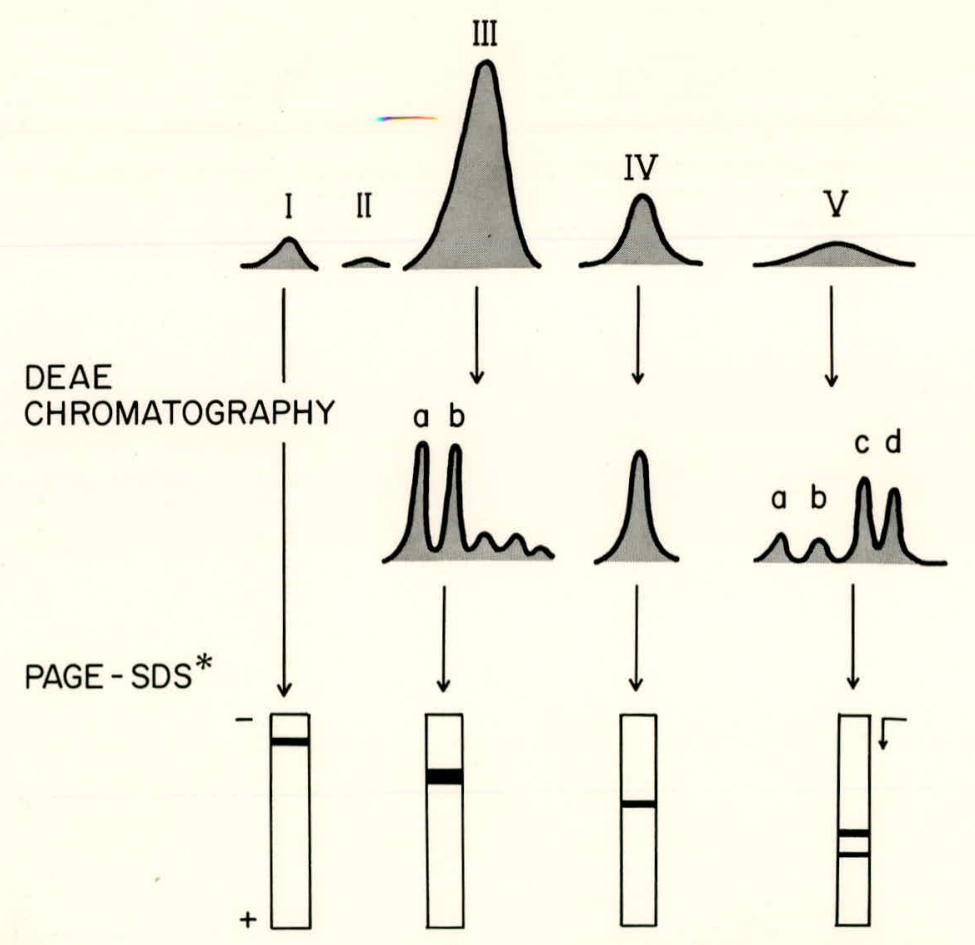

*Polyacrylamide gel-sodium dodecyl sulphate electrophoresis 